\title{
ANALISIS TINGKAT KESEHATAN KEUANGAN PERUSAHAAN ROKOK YANG TERDAFTAR DI BURSA EFEK INDONESIA (BEI)
}

\author{
Sri Yati \\ STIE Malangkuçeçwara Malang \\ Jln. Terusan Candi Kalasan, Blimbing \\ Malang - Indonesia 65142 \\ E-mail: sriati@stie-mce.ac.id
}

\begin{abstract}
The competitive advantages of the company's are mainly determined by the performance. One important aspects of performance is financial aspects which are illustrated in financial statements. However, it is not enough to only assess the financial performance of companies. It required the analysis of financial statements to obtain the whole picture of company's progress which is can be used by management or other users of financial statements to make decision making. The financial analysis in this research is used Z-Score to determine the company's financial performance more accurately and the health level of cigarettes companies in facing global competition and also dealing with the smoking ban regulations. The research was conducted on three tobacco companies that go public on the Stock Exchange Indonesia, that are PT Bentoel International Tbk., PT. Gudang Garam Tbk., PT. Hanjaya Mandala Sampoerna Tbk. Z-Score results showed that PT Bentoel International Tbk in 2008 and 2009 had a poor financial performance and classified as highly vulnerable company, whereas in 2010 the company was in a good performance and healthy condition. Meanwhile, PT Gudang Garam Tbk from 2008, 2009 and 2010 is classified as healthy company. PT. Hanjaya Mandala Sampoerna Tbk has a good financial performance and categorized as healthy company began in 2008, 2009 to 2010. To conclude, among the three tobacco companies that go public on the Stock Exchange Indonesia, PT Hanjaya Mandala Sampoerna Tbk is a company that has the best financial performance and classified as a healthy company.
\end{abstract}

Key word: Analisis Z Score, Penilaian Tingkat kesehatan keuangan perusahaan.

Situasi perekonomian di Indonesia sekarang ini membawa dampak persaingan yang semakin ketat di berbagai bidang industri. Untuk itu perusahaan harus dapat menghadapi persaingan yang ketat dalam bidang industrinya. Salah satu cara yang dapat diambil yaitu dengan meningkatkan kemampuan internalnya, baik berupa peningkatan teknologi, kualitas produk, kualitas sumber daya manusia, efisiensi biaya, maupun kinerja yang makin tinggi.

Salah satu industri yang sangat dapat menunjang pembangunan dan perkembangan ekonomi khususnya di Indonesia adalah industri rokok, baik dalam skala kecil, menengah, maupun besar. Walaupun industri rokok adalah industri yang 
kontroversial karena terbukti bahwa rokok dapat membahayakan kesehatan bahkan keselamatan jiwa, namun dalam kenyataannya industri rokok dan mata rantai distribusinya adalah penyerap tenaga kerja yang cukup besar dan menjadi tumpuan ekonomi bagi masyarakat. Di dalam kondisi yang penuh persaingan ini, setiap perusahaan pasti selalu ingin mengetahui dan memperbaiki kinerja perusahaan sesuai dengan visi dan misi yang dimiliki.

Penilaian kinerja keuangan dapat dilakukan melalui analisis laporan keuangan karena pada dasarnya laporan keuangan adalah hasil dari proses akuntansi yang dapat digunakan sebagai alat komunikasi antara data keuangan atau aktivitas suatu perusahaan dengan pihak-pihak yang berkepentingan. Analisis terhadap laporan keuangan dimaksudkan untuk membuat informasi dalam laporan keuangan yang bersifat kompleks menjadi elemen-elemen yang lebih sederhana dan mudah dipahami oleh pengguna laporan keuangan. Untuk itu diperlukan pengukuran kinerja keuangan perusahaan agar perusahaan dapat mengetahui pemanfaatan sumber daya yang dimiliknya. Selain itu pengukuran kinerja keuangan juga dapat membantu perusahaan untuk mengetahui apakah perusahaan dapat bertahan di lingkungan industrinya.

Kinerja keuangan perusahaan juga dapat di ukur dengan menggunakan analisis Z-Score. Analisis Z-Score bermanfaat untuk memprediksikan kebangkrutan atau tingkat kegagalan bisnis perusahaan. Hasil perhitungan $Z$ score tersebut perusahaan yang diamati dapat diklasifikasikan menjadi perusahaan yang sehat, ragu-ragu atau tidak sehat dan diprediksikan bangkrut. Hasil analisis juga dapat memberikan informasi yang bermanfaat bagi manajemen perusahaan, misalnya jika perusahaan masuk dalam kategori sehat, maka perusahaan harus dapat mempertahankan kinerja keuangannya, jika perusahaan masuk dalam kategori tidak sehat, maka perusahaan dapat mengambil tindakan perbaikan dengan menganalisis penyebab tidak sehatnya kondisi keuangan perusahaan. Dengan demikian hasil analisis Z-Score diharapkan dapat digunakan untuk memprediksi kinerja keuangan dan memberikan manfaat yang sangat berguna bagi kelangsungan usaha perusahaan di masa yang akan datang. Hal ini terkait dengan tujuan utama didirikannya suatu perusahaan adalah untuk menghasilkan pendapatan dan laba, dan tujuan tersebut dapat tercapai hanya jika perusahaan memiliki kinerja keuangan yang baik, yang akan tercermin dari laporan keuangannya. Informasi Analisis $Z$ score juga berfungsi bagi investor untuk mengetahui perkembangan kinerja keuangan dan 
tingkat kesehatan keuangan perusahaan, agar tujuan investasi untuk menghasilkan laba dapat tercapai. Maka dari itu pengetahuan tentang kinerja keuangan perusahaan sangat penting.

Persaingan yang semakin ketat antar perusahaan rokok seperti sekarang ini, maka perusahaan perlu mengetahui dan kesehatan perusahannya. Hal ini sangat bermanfaat bagi pemilik, pengelola, pihak investor dan calon investor, serta kreditur. Pengukuran kinerja dan kesehatan keuangan perusahaan dapat dilakukan melalui analisis laporan keuangan dengan menggunakan analisis Z-Score. Dari gambaran di atas, permasalahan dapat dirumuskan sebagai berikut: "Bagaimana penerapan analisis Z-Score untuk menilai kesehatan perusahan rokok yang Go Public di Bursa Efek Indonesia”

\section{Urgensi Laporan Keuangan}

Laporan keuangan merupakan hasil dari proses akuntansi yang dapat digunakan sebagai alat untuk berkomunikasi antara data keuangan dengan pengguna laporan keuangan. Menurut Munawir (2007:5) adalah "dua daftar yang disusun oleh akuntan pada akhir periode untuk suatu perusahaan. Kedua daftar itu adalah daftar neraca atau daftar posisi keuangan dan daftar pendapatan atau daftar rugi laba. Pada waktu akhirakhir ini sudah menjadi kebiasaan bagi perseroan-perseroan untuk menambahkan daftar ketiga yaitu daftar surplus atau daftar laba yang tak dibagikan (laba yang ditahan)”.

Sesuai dengan Pernyataan Standar Akuntansi Keuangan (PSAK) No. 1 tentang penyajian laporan keuangan dinyatakan bahwa laporan keuangan adalah suatu penyajian terstruktur dari posisi keuangan dan kinerja keuangan suatu entitas. Tujuan laporan keuangan adalah memberikan informasi mengenai posisi keuangan, kinerja keuangan, dan arus kas entitas yang bermanfaat bagi sebagian besar kalangan pengguna laporan dalam pembuatan keputusan ekonomi. Laporan keuangan juga menunjukkan hasil pertanggungjawaban manajemen atas penggunaan sumber daya yang dipercayakan kepada mereka. Laporan keuangan lengkap terdiri dari (a) laporan posisi keuangan (neraca) pada akhir periode, (b) laporan laba rugi komprehensif selama periode, (c) laporan perubahan ekuitas selama periode, (d) laporan arus kas selama periode, (e) catatan atas laporan keuangan, berisi ringkasan kebijakan akuntansi penting dan informasi penjelasan lainnya, dan (f) laporan posisi keuangan pada awal periode komparatif yang disajikan ketika entitas menerapkan suatu kebijakan akuntansi secara 
retrospektif atau membuat penyajian kembali pos-pos laporan keuangan, atau ketika entitas mereklasifikasi pos-pos dalam laporan keuangannya.

\section{Analisis Rasio Keuangan}

Menurut Frederick and Gary (2005) analisis rasio mencakup perbandingan rasio antara suatu perusahaan dengan perusahaan lain dalam industri yang sama, perbandingan rasio suatu perusahaan antarwaktu atau dengan periode fiscal yang lain, dan atau perbandingan rasio terhadap beberapa acuan yang baku. Rasio keuangan juga menggambarkan suatu hubungan matematis antara suatu jumlah tertentu dengan jumlah yang lain (Munawir, 2000).

Rasio dapat menjelaskan atau memberi gambaran tentang baik atau buruknya suatu keadaan terutama jika angka rasio tersebut dibandingkan dengan angka rasio pembanding yang digunakan sebagai standar. Manfaat suatu angka rasio juga tergantung pada kemampuan penganalisis dalam menginterpretasikan data yang bersangkutan. Berdasarkan analisis rasio keuangan adalah angka yang diperoleh dari hasil perbandingan dari satu pos laporan keuangan dengan pos lainnya yang mempunyai hubungan yang relevan dan signifikan (Harahap, 2004).

\section{Analisis Z-Score}

Studi yang dilakukan Altman (1968) dengan menggunakan Multivariate Discriminant Analysis untuk menentukan model yang disebut Z-Score, yaitu score dari kombinasi rasio-rasio keuangan untuk menentukan prediksi kesulitan keuangan perusahaan. Variabel yang digunakan dalam model meliputi: Working capital to total assets, Retained earning to total assets, EBIT to total assets, Market value of equity to book value of total liabilities, Sales to total assets. Kelima rasio yang digunakan tersebut ternyata bisa digunakan untuk mendeteksi kebangkrutan perusahaan. (Rame,2006).

Analisis Z-Score menurut Hanafi dan Halim (2003) adalah model prediksi kebangkrutan sudah dikembangkan ke beberapa Negara. Altman $(1983,1984)$ melakukan survei model-model yang dikembangkan di Amerika Serikat, Jepang, Jerman, Swiss, Brasil, Australia, Inggris, Irlandia, Kanada, Belanda dan Perancis. Salah satu masalah yang bisa dibahas adalah apakah ada kesamaan rasio keuangan yang bisa dipakai untuk prediksi kebangkrutan untuk semua negara, ataukah mempunyai kekhususan. 


\section{METODE}

Sumber data penelitian ini menggunakan sumber data sekunder Data sekunder yang diperoleh dari BEI (Bursa Efek Indonesia) berupa neraca perusahaan 2008-2010 dan laporan laba rugi perusahaan 2008-2010. Populasi pada penelitian ini adalah seluruh sektor industri manufaktur yang go public di Bursa Efek Indonesia (BEI) untuk periode pengamatan tahun 2008 sampai 2010 khusus untuk perusahaan rokok. Dari populasi tersebut telah ditentukan dan dipilih beberapa sampel dilakukan dengan cara purposive sampling, yaitu tipe pemilihan sampel secara acak yang informasinya diperoleh dengan pertimbangan tertentu Tyas, 2006:35)

Perusahaan rokok yang go public di Bursa Efek Indonesia (BEI) untuk periode pengamatan tahun 2008 sampai 2010 yaitu: (1) PT. Bentoel International Tbk (2) PT. BAT Indonesia Tbk. (3) PT. Hanjaya Mandala Sampoerna Tbk. (4) PT. Gudang Garam Tbk. Berdasarkan pertimbangan dari seluruh perusahaan rokok yang go public di Bursa Efek Indonesia (BEI) untuk periode pengamatan tahun 2008 dan 2010 telah dipilih sampel yaitu: (1) PT. Bentoel International Tbk, (2) PT. Gudang Garam Tbk, (3) PT. Hanjaya Mandala Sampoerna Tbk

Peneliti mengambil pertimbangan tiga perusahaan Jaitu PT. Bentoel International Tbk walaupun sudah di beli oleh PT. BAT Indonesia Tbk.masih tetap listing di BEI. Sedangkan PT. BAT Indonesia Tbk mengalami kerugian dari tahun ke tahun dan tidak diambil sebagai sample penelitian. Karena itu peneliti ingin melihat kesehatan ketiga perusahaan rokok Jaitu PT. Bentoel International Tbk, PT. Gudang Garam Tbk, dan PT Hanjaya Mandala Sampoerna Tbk yang memiliki proporsi yang sama. Antara lain: (a) Jenis perusahaan sama,yaitu sama-sama perusahaan dalam bidang rokok, (b) Rutin terdaftar di Bursa Efek Indonesia(BEI) selama periode pengamatan tahun 2008 sampai 20010

Metode yang digunakan dalam penelitian ini adalah teknik pengumpulan data arsip. Karena data yang digunakan adalah data sekunder, maka teknik yang digunakan adalah teknik pengumpulan data arsip di basis data. Metode menggunakan Analisis ZScore untuk Perusahaan go public dengan formulasi sebagai berikut:

$$
\mathrm{Z}=1,2 \mathrm{X} 1+1,4 \mathrm{X} 2+3,3 \mathrm{X} 3+0,6 \mathrm{X} 4+1,0 \mathrm{X} 5
$$

Keterangan : 


$$
\begin{aligned}
& \text { X1 }=\text { Modal Kerja } / \text { Total Aktiva }(\%) \\
& \text { X2 }=\text { Laba Ditahan } / \text { Total Aktiva }(\%) \\
& \text { X3 }=\text { EBIT atau Laba Usaha } / \text { Total Aktiva (\%) } \\
& \text { X4 }=\text { Nilai Pasar Saham } / \text { Total Hutang }(\%) \\
& \text { X5 }=\text { Penjualan } / \text { Total Aktiva }(\mathrm{x})
\end{aligned}
$$

Analisis ini digunakan untuk meramalkan tingkat kebangkrutan atau kegagalan perusahaan, untuk mengetahui kesehatan keuangan dan memprediksi apakah perusahaan berkembang baik atau menurun kondisi keuangannya. Pengukuran yang digunakan adalah:

\section{a) X1 (Modal Kerja Bersih/Total Aktiva)}

Digunakan untuk mengukur tingkat efisiensi dalam penggunaan modal yang tersedia pada suatu perusahaan. Sehingga semakin kecil nilai yang dihasilkan semakin efisien perusahaan tersebut dalam menggunakan modal kerja. Tetapi jika dihubungkan dengan likuiditas, semakin kecil nilai tersebut berarti semakin tinggi pula resiko perusahaan mengalami kegagalan dalam menjamin hutang.

b) X2 ( Laba Ditahan/Total Aktiva)

Digunakan untuk mengukur profitabilitas kumulatif. Semakin besar nilai yang dihasilkan maka semakin kecil ketergantungan perusahaan terhadap pihak eksternal sehingga untuk melaksanakan kegiatan operasionalnya, perusahaan masih dapat mengandalkan sumber dana dari pihak internal baik itu melalui modal saham ataupun juga laba ditahan.

c) X3 (EBIT/Total Aktiva)

Digunakan untuk mengukur produktivitas yang sebenarnya dari aktiva perusahaan yaitu efektifitas perusahaan dalam menggunakan sumber dananya sebelum dikurangi pajak dan bunga. Semakin besar nilai yang dihasilkan semakin baik kinerja perusahaan. Sebaliknya, semakin kecil nilai yang dihasilkan semakin memperlihatkan tidak efektifnya perusahaan dalam mengelola sumber dananya yang digunakan sebagai penunjang kegiatan operasional perusahaan dalam menghasilkan laba

d) X4 (Nilai Pasar Modal Saham Biasa dan Preferen/Nilai Buku Tahun Hutang) Menunjukkan kemampuan saham perusahaan dalam menjamin hutang. Semakin besar nilainya semakin besar pula kemampuan saham perusahaan dalam menjamin 
hutang. Dengan kata lain, semakin besar rasio berarti semakin rendah pula tingkat resiko financial perusahaan.

a) X5 (Penjualan/Total Aktiva)

Digunakan untuk mengukur efektifitas perusahaan dalam menghasilkan jumlah penjualan dengan menggunakan aktiva perusahaan. Tingginya rasio ini menunjukkan penggunaan Total aktiva yang efektif dalam menghasilkan penjualan. Sedangkan aktiva yang tidak digunakan dalam operasi akan membebani hasil rasio tersebut karena dianggap tidak produktif.

Perusahaan dikategorikan Sehat jika nilai $Z>2,99$, rawan jika nilai $Z$ berkisar antara 1,81s/d 2,99 dan tidak sehat/bangkrut jika nilai $\mathrm{Z}<1,81$.

\section{HASIL DAN PEMBAHASAN}

Berdasarkan hasil perhitungan $\mathrm{Z}$ Score dan hasil perhitungan variabel X1, $\mathrm{X} 2, \mathrm{X} 3, \mathrm{X} 4$ dan X5, maka berikut ini akan diketahui kondisi keuangan dari P.T. Bentoel International Tbk., P.T. Gudang Garam Tbk, PT. Hanjaya Mandala Sampoerna Tbk., Berikut ini disajikan rangkuman hasil perhitungan Z-Score masing-masing perusahaan

Hasil Analisa Z-Score

\begin{tabular}{|l|c|c|c|}
\hline & \multicolumn{3}{|c|}{ Keterangan (tahun) } \\
\hline \multicolumn{1}{|c|}{ PERUSAHAAN } & $\mathbf{2 0 0 8}$ & $\mathbf{2 0 0 9}$ & $\mathbf{2 0 1 0}$ \\
\hline PT. Bentoel International Tbk. & 2,958 & 2,8179 & 4,066 \\
& rawan & rawan & sehat \\
\hline PT. Gudang Garam Tbk. & 3,579 & 6,04 & 8,227 \\
& sehat & sehat & sehat \\
\hline PT. Hanjaya Mandala Sampoerna Tbk. & 6,905 & 8,463 & 11,663 \\
& sehat & sehat & sehat \\
\hline
\end{tabular}

Sumber : data mentah yang diolah

\section{Evaluasi Masing-Masing Perusahaan Rokok atas Perhitungan Z- Score}

\section{PT Bentoel International Tbk.}

Kondisi keuangan perusahaan yang buruk diperlihatkan model analisis Z-score pada tahun pertama dan kedua pengamatan. Buruknya kinerja keuangan pada tahun 2008-2009 ternyata dapat diperbaiki oleh manajemen perusahaan pada tahun 2010. Hal ini ditunjukan dengan menaiknya nilai $\mathrm{Z}$ yang diperoleh perusahaan pada tahun terakhir. 
Kondisi keuangan perusahaan membaik pada tahun 2010, hal tersebut ditunjukkan dari hasil analisis $\mathrm{Z}$ score yang meningkat. Pihak manajemen perlu mengambil beberapa langkah perbaikan dengan melihat hasil perhitungan model analisis Z-score.

Langkah-langkah yang harus ditempuh manajemen perusahaan yaitu, pertama, menekan sejumlah biaya terutama pada biaya operasional perusahaan, melakukan pengembangan pasar dengan memaksimalkan jaringan distribusi perusahaan. Dengan tetap fokus pada produk utama perusahaan, hal ini dilakukan untuk menunjang mutu produk sehingga mempunyai daya saing yang tinggi terutama untuk pasar luar negeri. Fokus pada produk utama juga sangat membantu perusahaan pada pengembangan produk terutama dalam hal meningkatkan variasi mutu produk. Selain itu melakukan strategi promosi yang tepat dan efektif juga sangat diperlukan dalam meningkatkan brand product.

Langkah-langkah tersebut diharapkan akan membantu untuk meningkatkan volume penjualan, EBIT yang diperoleh dan Laba ditahan perusahaan sehingga akan mengurangi kesulitan keuangan yang dialami perusahaan dalam beberapa tahun terakhir. Kedua, pihak manajemen juga bisa berusaha meningkatkan produksi dan peningkatan penjualan atas produk yang mempunyai nilai tambah. Berusaha untuk memproduksi dengan kapasitas penuh dan menjual seluruh hasil produksinya. Langkah yang lain yaitu dengan melakukan kontrol atas investasi peralatan, memperkuat jaringan pemasaran, melakukan pengembangan produk baru. Selain itu peningkatan efisiensi produksi seiring meningkatnya tarif listrik untuk industri dan kenaikan harga minyak juga sangat perlukan diperhitungkan perusahaan ini.

\section{PT. Gudang Garam Tbk.}

Berdasarkan hasil perhitungan Z-Score selama tiga tahun didapat nilai yang menunjukkan kondisi yang semakin baik dari tahun 2008 sampai dengan tahun 2010. Hal ini diketahui dengan mengamati nilai $\mathrm{Z}$ pada kurun waktu 3 tahun selalu meningkat dari kisaran tahun $2008=3,579$ tahun $2009=6,04$ tahun $2010=8,227$. Keadaan ini mengindikasikan terdapat peningkatan kinerja keuangan perusahaan yang bagus. Peningkatan tersebut disebabkan oleh beberapa faktor diantaranya yaitu perusahaan berhasil mengurangi tingkat kerugian sebelum bunga dan pajak yang diperoleh 
perusahaan tahun sebelumnya. Selain itu perusahaan juga berhasil meningkatkan pendapatan bersih dari tahun 2008, 2009, 2010.

Pihak manajemen dapat mengambil beberapa langkah-langkah berdasarkan hasil analisasi yaitu dengan cara pertama, meningkatkan jumlah penjualan dan efisiensi pada proses produksi sehingga diharapkan terjadi peningkatan pada laba operasi dan laba ditahan perusahaan. Peningkatan jumlah penjualan dapat dilakukan perusahaan dengan melakukan perluasan pasar dan menciptakan segmen pasar baru untuk beberapa produk perusahaan. Kedua, meningkatkan variasi mutu atau mengembangkan beragam tingkat mutu hal ini untuk mengatasi semakin merosotnya daya beli konsumen dalam negeri. Ketiga, mendapatkan tambahan dana untuk meningkatkan modal kerja dan likuiditas perusahaan merupakan langkah yang perlu dilakukan pihak manajemen, penawaran saham baru kepada publik dan mempercepat perputaran piutang merupakan beberapa cara yang dapat dilakukan oleh manajemen.

\section{PT. Hanjaya Mandala Sampoerna Tbk.}

Hasil perhitungan menggunakan model diskriminan altman diketahui bahwa PT. Hanjaya Mandala Sampoerna Tbk kondisi keuangan yang sehat, nilai z-score perusahaan ini memiliki kecenderungan meningkat. Hal ini ditunjukkan dengan meningkatnya nilai Z-score tahun $2008=6,905$ naik menjadi 8,463 pada tahun 2009 dan kemudian tahun 2010 mengalami kenaikan lagi mencapai 11,663. Pada awal tahun pengamatan 2008 perusahaan berada pada kondisi sehat. Tetapi pada tahun 2009 perusahaan berhasil untuk meningkatkan kinerja keuangannya dan justru kondisi keuangan perusahaan mengalami peningkatan dan masih pada posisi sehat. Pada tahun 2010 tambah semakin bagus.

Berdasarkan kondisi di atas maka langkah-langkah yang dapat ditempuh pihak manajemen yaitu pertama, berusaha meningkatkan penjualan ekspor produk perusahaan ke beberapa negara Asia, Eropa dan Amerika. Meningkatkan produksi dan peningkatan penjualan atas produk yang mempunyai nilai tambah. Kedua, berusaha untuk memproduksi dengan kapasitas penuh dan menjual seluruh hasil produksinya, hal ini sangat penting dikarenakan adanya kecenderungan peningkatan permintaan terhadap produk utama perusahaan yaitu rokok kretek Dji Sam Soe pada beberapa tahun terakhir.

Langkah yang lain yaitu dengan melakukan kontrol atas investasi peralatan, memperkuat jaringan pemasaran, melakukan pengembangan produk baru dan menekan 
biaya pemasaran baik didalam maupun luar negeri. Selain itu peningkatan efisiensi produksi seiring meningkatnya tarif listrik untuk industri dan kenaikan harga minyak juga sangat diperlukan perusahaan ini.

\section{KESIMPULAN DAN SARAN}

\section{Kesimpulan}

Berdasarkan hasil analisis terhadap perusahaan rokok yang terdaftar di BEI menunjukkan bahwa semakin kecil Z-Score yang dimiliki suatu perusahaan mengindikasikan semakin besar kesulitan keuangan yang dialami perusahaan tersebut, sebaliknya semakin besar Nilai Z suatu perusahaan mengindikasikan semakin baiknya kondisi keuangan perusahaan.

Berdasarkan analisis terhadap lima rasio keuangan yang menjadi variabel Z Score (X1-X5) pada tiap perusahaan yang diteliti menunjukkan bahwa secara umum rasio X5 atau rasio penjualan terhadap total aktiva merupakan rasio yang paling dominan dalam penentuan nilai Z, karena selalu bernilai terbesar diantara empat rasio yang lain (X1 $\mathrm{X} 4$ ). Sedangkan rasio yang bernilai kecil sebagaian besar adalah rasio X1 (rasio modal kerja terhadap total aktiva) dan rasio X2 (rasio laba ditahan) terhadap total aktiva.

Hasil model analisis Z-score menunjukkan bahwa pada tahun 2008 dan 2009 PT Bentoel International Tbk. Menngalami kesulitan/rawan keuangan, sedangkan untuk tahun 2010 kondisi perusahatan tersebut sudah baik dan sehat. PT. Gudang Garam Tbk yang diteliti mulai tahun 2008, 2009 dan 2010 kondisi keuangannya sehat. PT. HM. Sampoerna Tbk mulai tahun 2008, 2009 dan 2010 menunjukkan keadaan keuangan yang masih sehat.

\section{Saran}

Berdasarkan hasil penelitian disarankan sebaiknya para analis laporan keuangan, para manajer keuangan, kreditur dan para calon investor, kiranya tidak cukup hanya menganalisis dengan satu model analisis tertentu dalam menilai keadaan keuangan dan tingkat kesulitan atau tingkat kesehatan suatu perusahaan untuk membuat penilaian keputusan terhadap perusahaan tersebut. Analisis laporan keuangan suatu perusahaan perlu ditinjau dari beberapa model analisis yang ada, sehingga diharapkan akan 
diperoleh hasil analisis yang lebih mendalam dan akurat serta dapat dihasilkan suatu keputusan yang lebih tepat.

Pihak manajemen perusahaan hendaknya segera mengambil tindakan pembenahan atau pencegahan, jika diketahui kondisi keuangan atau tingkat kesehatan perusahaan semakin menurun dan menunjukkan gejala penurunan. Hal tersebut dapat diamati dari perkembangan Nilai $\mathrm{Z}$ dan kebangkrutan perusahaan selama beberapa tahun, buruknya kondisi keuangan perusahaan dapat dilihat dari menurunnya Nilai Z perusahaan dan semakin meningkatnya kebangkrutan perusahaan dari tahun ke tahun. Agar dapat memperbaiki kondisi keuangan atau tingkat kesehatan perusahaan yang direfleksikan dengan hasil dari model analisis Z-Score maka disarankan untuk lebih memperhatikan pada tiap-tiap Rasio Keuangan yang menjadi unsur pembentuknya.

Perusahaan-perusahaan rokok yang beroperasi di Indonesia terutama beberapa perusahaan rokok yang terdaftar di Bursa Efek Indonesia yang menjadi obyek penelitian ini disarankan untuk meningkatkan penjualan produk perusahaan dengan melakukan perluasan atau pengembangan pasar, memperkuat jaringan pemasaran dan melakukan inovasi atau pengembangan produk untuk beberapa produk perusahaan yang telah mencapai titik jenuh.

Selain itu perusahaan disarankan untuk berusaha menekan atau mereduksi sejumlah Inefisiensi dalam proses produksi yang menyebabkan peningkatan pada biaya produksi. Mempertahankan dan berusaha meningkatkan mutu produk perusahaan merupakan langkah yang perlu dilakukan perusahaan untuk mendukung daya saing produk terutama untuk pasar ekspor. Untuk memperoleh tambahan dana yang cukup besar, perusahaan disarankan untuk menambah jumlah saham yang beredar dengan melakukan penawaran saham baru kepada publik.

\section{DAFTAR PUSTAKA}

Altman, E. I. 1968, Financial Ratios, Discriminant Analysis and The Predictionof Corporate Bankcuptcy, The journal of Finance, Sept.

Altman, Edward I., 1983. Corporate Financial Distress: A complete Guide to Predicting, Avoiding, and Dealing With Bankruptcy. New York: WileyInterscience Publication. 
Budi, Rame, B, S 2006. Analisis Rasio Keuangan dan Z-Score Guna Mengukur Kinerja Perusahaan Go Publik Dalam Industri Manufaktur Makanan. Skripsi. STIE MalangKuçeçwara, Malang.

Hanafi, Mamduh M dan Abdul Halim, 2003, Analisis Laporan Keuangan, Edisi Revisi, Cetakan Pertama, UPP AMP YKPN, Yogyakarta.

Harahap, Sofyan, S 2004. Analisis Kritis Atas Laporan Keuangan. Edisi Pertama. Cetakan Keempat Penerbit PT. RajaGrafindo Persada, Jakarta

Ikatan Akuntan Indonesia. 2009. Pernyataan Standar Akuntansi Keuangan No. 1 tentang Penyajian Laporan Keuangan (Revisi 2009)

Jogiyanto. 2007. Metodologi Penelitian Bisnis: Salah Kaprah dan PengalamanPengalaman. Yogyakarta: BPFE

Munawir, S. 2000. Analisa Laporan Keuangan edisi keempat. Yogyakarta: Liberty

Retnoningrum, Tyas, A (2006). Penerapan Economic Value Added dan Analisis RasioUntuk Mengklasifikasikan Kesehatan Bank Yang Go Publik Di Bursa Efek Jakarta. Skripsi. Universitas Brawijaya, Malang.

www.bapepam.go.id, (2005), Studi Tentang Analisis Laporan Keuangan Secara Elektronik, Jakarta. 